\title{
EVALUATION OF TOTAL HYDROCARBON LEVELS IN SOME AQUATIC MEDIA IN AN OIL POLLUTED MANGROVE WETLAND IN THE NIGER DELTA
}

\author{
H. IBIGONI CLINTON ${ }^{1 *}-$ G. UGWEMORUBONG UJAGWUNG $(\text { SNR. })^{2}-$ M. HORSFALL (JNR.) ${ }^{3}$ \\ ${ }^{1}$ Department of Chemistry/Biochemistry Federal Polytechnic, Nekede, Owerri. Imo State, \\ Nigeria \\ ${ }^{2}$ Department of Fisheries, Rivers State University of Science and Technology Port Harcourt, \\ Rivers State Nigeria \\ ${ }^{3}$ Department of Pure and Industrial Chemistry, University of Port Harcourt, Port Harcourt, \\ Rivers state Nigeria \\ *Corresponding author \\ e-mail: ibigoni_chi@yahoo.co.uk
}

(Received $30^{\text {th }}$ April 2008 ; accepted $6^{\text {th }}$ July 2009)

\begin{abstract}
The total hydrocarbon (THC) levels in the surface waters, sediments and biota in an oil polluted mangrove wetland located in the Niger Delta Nigeria, were studied between November 2001 and October 2002. Result showed elevated THC mean levels in water $(23.6 \pm 4.3 \mathrm{mg} / \mathrm{l})$, sediment $(386.44 \pm$ $50.28 \mu \mathrm{g} / \mathrm{g})$, Tympanotonus fuscatus (Periwinkle) $(449.30 \pm 55.42 \mu \mathrm{g} / \mathrm{g})$ and Periophthalmus papillio (Mudskipper) $(278.57 \pm 34.57 \mu \mathrm{g} / \mathrm{g})$, indicating a polluted environment. THC levels in water at the wellhead stations were above $10 \mathrm{mg} / \mathrm{l}$ being the maximum recommended limit by the Federal Ministry of Environment (FMENV) Nigeria. There was a pronounced seasonal variability with the highest being in the dry season $(\mathrm{P}<0.05)$ due to the higher level of increased oil activity in that season. THC levels in water correlated significantly $(\mathrm{r}=0.927)$ with THC levels in the sediment $(\mathrm{P}<0.01)$. The implication is that as the THC remains within the surface water column in relation to the sediment the more the organisms in the environment are impacted. This is shown by the significant correlations $(\mathrm{P}<0.01)$ of THC between the organisms and their surrounding media. The high levels of THC in the surface water and sediments of these stations suggest that aquatic life water quality may adversely influence biological functions of exposed species, while the level in the Tympanotonus fuscatus and the Periophthalmus papillio calls for concern as it can have some health-risk implications in man who is the final consumer.
\end{abstract}

Key words: Molluscs, biota, bioaccumulation, hydrocarbon

\section{Introduction}

The extraction and usage of petroleum products as energy sources the world over has led to a widespread pollution of the bioshpere. About 6-10 million barrels of crude oil enter the aquatic environment yearly [1]. The control of such pollution problems in the aquatic environment is very difficult because of the large number of input sources and their geographic dispersions. Contrary to popular views, evidence is accumulating to buttress the fact that petroleum hydrocarbon mixes with water and penetrates to the underlying sediments $[2,3,4]$. The resultant effects of the above are a change in desirable portable water characteristics [5];impaired growth of marine organisms which depend basically on the quantity and quality of the primary production of phytoplankton, fish, crustaceans and molluscs acquire objectionable odour or falvour, thereby causing a reduction in their marketability and acceptance as food [6, 7]. Death of the fauna and flora from oil spills is common place in the Niger Delta region of 
Nigeria where the most intensive oil exploration, exploitation and refining occur [8]. Besides, oil contamination of coastal amenities has adverse effects on tourism, recreation and aesthetics of the impacted area. This effect can be substantial on a community whose economy depends on tourism.

Mudskipper (Periophthalmus papillio) and Periwinkles (Tympanotonus fuscatus var. radula) are of economic importance to the natives in the Niger Delta. Periwinkles are rich in protein $(21.04 \%)$ and carbohydrates and are gathered daily for food [9]. Their nutritional values compare favourably with those of domestic livestock and fish [7]. Like all other intertidal organisms musdskipper and periwinkles are very vulnerable to oil pollution because their habit are susceptible to coating with oil and may be smothered in the event of heavy oil drifting ashore. The creek and its environs bearing the flow station facilities play important role in the economic well being of the natives of the area as they ferment cassava into raw 'fufu' (locally made starchy food) from dug out holes on the mudflats of the area and fishing operations that is being carried out on a daily basis.

The aim of this research was to provide information on the total hydrocarbon status of the surface waters, sediments and biota (periwinkle and mudskipper) of the area.

\section{Study area}

The area is a mangrove wetland with lots of creeks and creeklets that links up to the lower reaches of the New Calablar River. The creeks are characterized by high seawater inflow and low freshwater input from runoffs of domestic wastewater, adjoining farmlands and forest and intense oil exploration and exploitation activities. Five sampling stations were chosen within the study area as indicated in Fig.l.

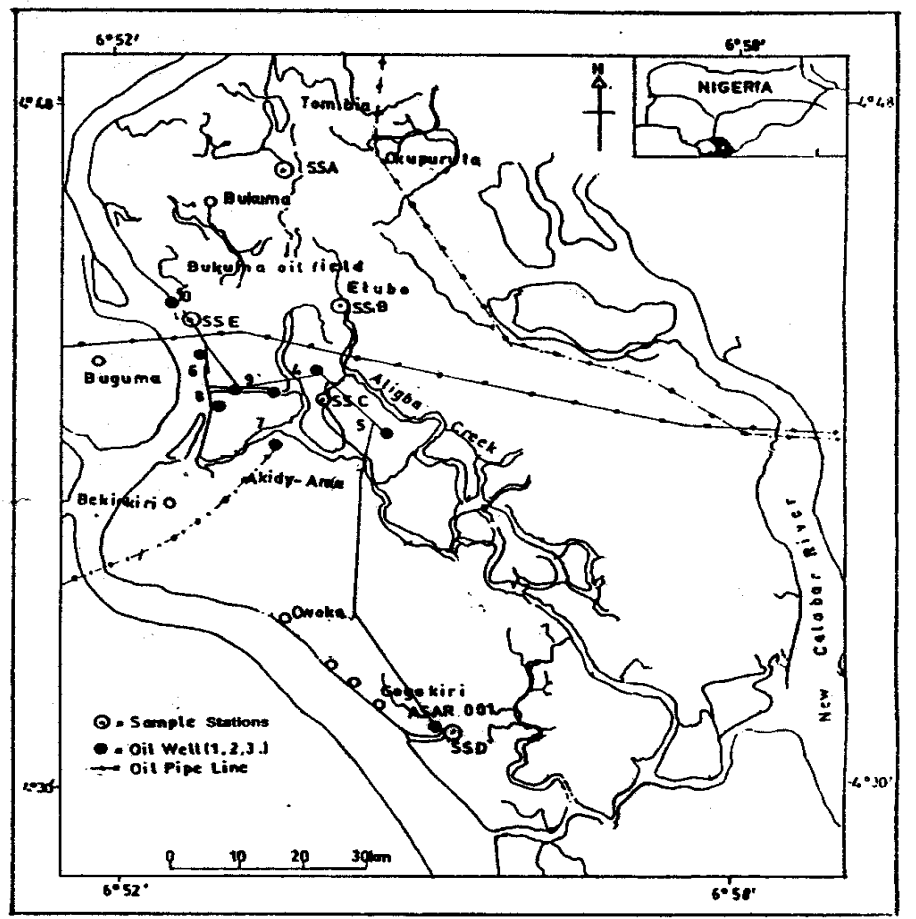

Figure 1. Map of the study area showing sampling stations 
Station A (SSA- reference) was an area without any industrial activities, except local fishing, periwinkle picking, etc. Station B (SSB) was an extension of the main creek (wherein the flow station was located) that leads to farmlands and where fermentation of cassava on the mangrove mudflats of the area was carried out. Station C (SSC) was the flow station that bears crude oil production facilities. There was also a nearby oil wellhead. Station D (SSD) was along a navigational route for barges and outboard and inboard engine boats. It had an oil wellhead. Station E (SSE) was a highly disturbed area by a recent oil and gas blow out from the oil wellhead. Most of the mangrove trees were destroyed. There was also an intense surface water runoff from the adjourning farmlands and forest.

\section{Materials and Methods}

Water and sediment samples were collected by the method of [10], while periwinkles $(3.0 \pm 0.5 \mathrm{~cm}$ mean length) and mudskippers $(3.5 \pm 0.5 \mathrm{~cm}$ mean length) were collected according to [7 and 11], respectively. Each sample was concurrently collected in triplicates from each station bi-monthly between November, 2001 and October, 2002.

In the laboratory (Institute of Pollution Studies Rivers State University of Science and Technology Port Harcourt) the sediment samples were air dried for four days, while the periwinkle and fish samples were frozen. Frozen samples were later thawed and the whole muscle tissues of the periwinkles were chucked out from the shells. The muscle tissues of the mudskippers were dissected out. Samples were dried on aluminum foil by heating in an oven at $50^{\circ} \mathrm{C}$ for 48 hours to constant weight. Heat treatment had the advantage of preserving the tissue for longer period. Besides it simulates the process they undergo before consumption in the Niger Delta area [7].

Tissue samples were ground in a teflon mortar, while the sediment samples were macerated and then sieved through a $1 \mu \mathrm{m}$ sieve for total hydrocarbon (THC) determination. $5.0 \mathrm{~g}$ each of the sieved samples were later extracted with two $25.0 \mathrm{ml}$ portions of toluene. The sieved samples were shaken on a Stuart flask shaker for 10 mins. The extracts were later filtered into $50.0 \mathrm{ml}$ flasks and made up to the $50.0 \mathrm{ml}$ mark with toluene. Total hydrocarbon from the water samples were extracted with $30 \mathrm{ml}$ toluene for three consecutive times and later made up to $100 \mathrm{ml}$. The absorbances of the filtrates were measured spectrophotometrically at $420 \mathrm{~nm}$ with a Spectrophotometer 21D [12 and 13]. The concentration calculated from the calibration graph on dry weight basis. Appropriate blanks were run throughout the procedure.

Data were analysed by a multivariate analysis of variance and means reported by Duncan's Multiple Range Test (DMRT). The THC periwinkles and fish tissues were correlated with that in surface water and sediment [14]. The level of significance was set at $95 \%$ and $99 \%$, respectively.

\section{Results}

The total hydrocarbon content of all the media differed in the sampling period and sites (Table 1.; Figs. 2. and 3.). The trend of concentrations from all the media deferred significantly $(\mathrm{P}<0.05)$, thus periwinkle $>$ sediment $>$ mudskipper $>$ surface water, while that of the stations was $\mathrm{SSE}>\mathrm{SSC}>\mathrm{SSD}>\mathrm{SSB}>\mathrm{SSA}$ (Fig. 4.) and the seasonal variation was: dry $>$ wet season (Fig. 5.), except in the mudskipper muscles. In all the months of the study (November 2001 - October 2002) the levels of THC were higher $(\mathrm{P}<0.05)$ in 
the periwinkle tissues than the other media (Fig. 4.). The monthly trend of all the metal levels in all the media within the study period was March=Jan $>$ May=Nov $>$ July $>$ November $=$ September (Fig. 3.).

Table 1. Mean values of the total hydrocarbon content of four media from the study area in comparison with other related studies

\begin{tabular}{|c|c|c|c|c|c|}
\hline $\begin{array}{c}\text { STNs of } \\
\text { this } \\
\text { study/Oth } \\
\text { er Studies }\end{array}$ & $\begin{array}{c}\text { Surface waters } \\
(\mathbf{m g} / \mathbf{l})\end{array}$ & $\begin{array}{c}\text { Sediment } \\
(\mu \mathrm{g} / \mathrm{g})\end{array}$ & $\begin{array}{c}\text { Periwinkle tissues } \\
(\mu \mathrm{g} / \mathrm{g})\end{array}$ & $\begin{array}{c}\text { Mudskipper Fish } \\
\text { Muscles } \\
(\mu \mathrm{g} / \mathrm{g})\end{array}$ & $\begin{array}{c}\text { STNs TOTAL } \\
\text { MEAN/Other } \\
\text { References }\end{array}$ \\
\hline A & $4.07 \pm 1.44^{\mathrm{c}}$ & $112.31 \pm 17.96^{\mathrm{e}}$ & $134.61 \pm 9.26^{\mathrm{c}}$ & $121.51 \pm 14.75^{\mathrm{e}}$ & $93.13 \pm 49.61^{e}$ \\
$\mathrm{~B}$ & $6.51 \pm 2.06^{\mathrm{c}}$ & $190.49 \pm 15.13^{\mathrm{d}}$ & $194.28 \pm 25.00^{\mathrm{c}}$ & $208.73 \pm 30.54^{\mathrm{cd}}$ & $150.00 \pm 85.21^{d}$ \\
$\mathrm{C}$ & $40.66 \pm 3.79^{\mathrm{a}}$ & $514.11 \pm 71.14^{\mathrm{ab}}$ & $664.35 \pm 78.81^{\mathrm{ab}}$ & $381.21 \pm 46.40^{\mathrm{a}}$ & $400.08 \pm 155.63^{b}$ \\
$\mathrm{D}$ & $21.05 \pm 5.35^{\mathrm{b}}$ & $457.98 \pm 56.67^{\mathrm{c}}$ & $541.15 \pm 76.64^{\mathrm{ab}}$ & $266.36 \pm 46.41^{\mathrm{c}}$ & $321.64 \pm 108.74^{c}$ \\
$\mathrm{E}$ & $45.71 \pm 8.86^{\mathrm{a}}$ & $657.31 \pm 95.14^{\mathrm{a}}$ & $712.10 \pm 83.37^{\mathrm{ab}}$ & $415.06 \pm 34.80^{\mathrm{a}}$ & $457.55 \pm 169.45^{a}$ \\
\hline TOTAL & $23.60 \pm 4.30^{d}$ & $386.44 \pm 50.28^{b}$ & $449.30 \pm 55.42^{a}$ & $278.57 \pm 34.57^{c}$ & \\
MEAN & & & & & \\
\hline
\end{tabular}

Within column (Stations), mean \pm sem with different superscript are significantly different at $P<0.05$ For the total mean (media), mean \pm sem with different superscript are significantly different at $P<0.05$ Stations total mean \pm sem with different superscript are significantly different at $P<0.05$

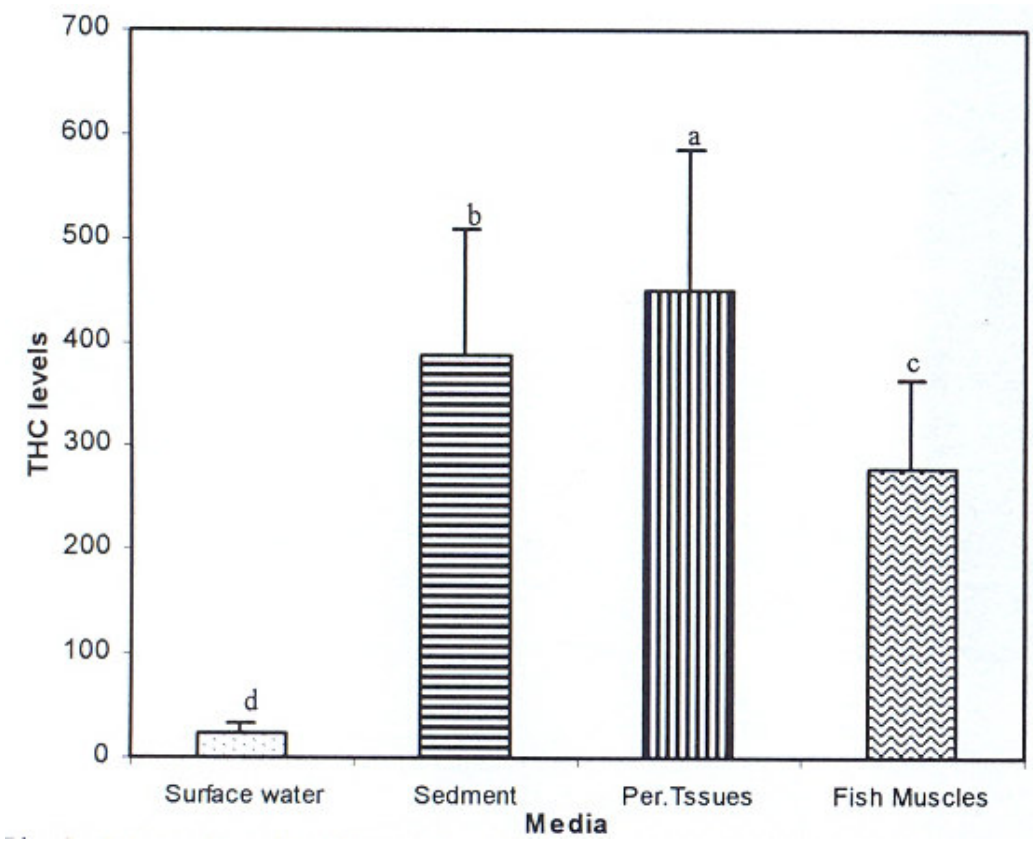

Figure 2. Mean levels of THC in the surface water ( $m g / l)$, Sediment $(\mu g / g)$, Periwinkle tissues $(\mu \mathrm{g} / \mathrm{g})$ and Mudskipper fish muscles $(\mu \mathrm{g} / \mathrm{g})$ from the study area. Note: Superscripts with different alphabets are significantly different $(P<0.05)$ 


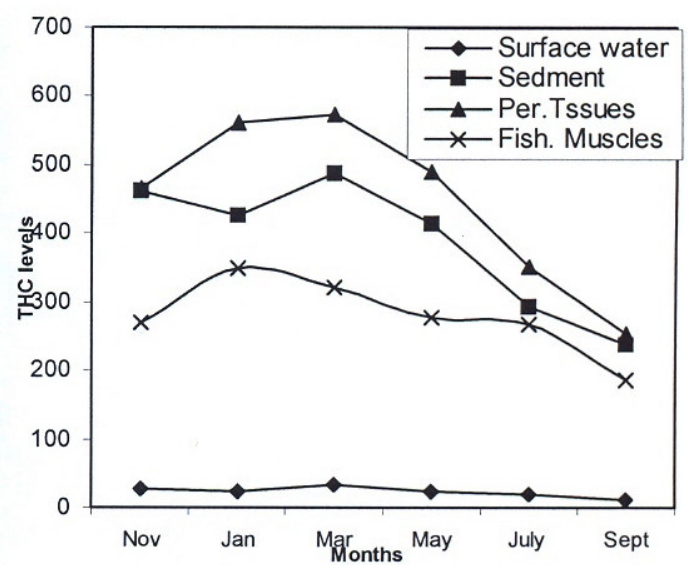

Figure 3. Monthly variations of THC in the Sediments $(\mu g / g)$ and surface water $(\mathrm{mg} / \mathrm{l})$ Periwinkle tissues $(\mu \mathrm{g} / \mathrm{g})$ and Mudskipper fish muscles $(\mu \mathrm{g} / \mathrm{g})$ from the study area.

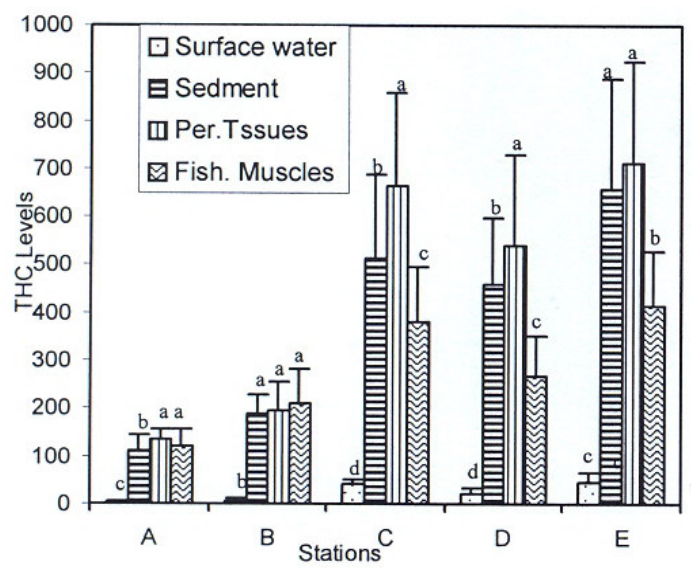

Figure 4. Stations variations of THC in the surface water ( $m g / l)$, Sediment $(\mu g / g)$, Periwinkle tissues $(\mu \mathrm{g} / \mathrm{g})$ and Mudskipper fish muscles $(\mu \mathrm{g} / \mathrm{g})$ from the study area. Note: Superscripts with different alphabets are significantly different $(P<0.05)$

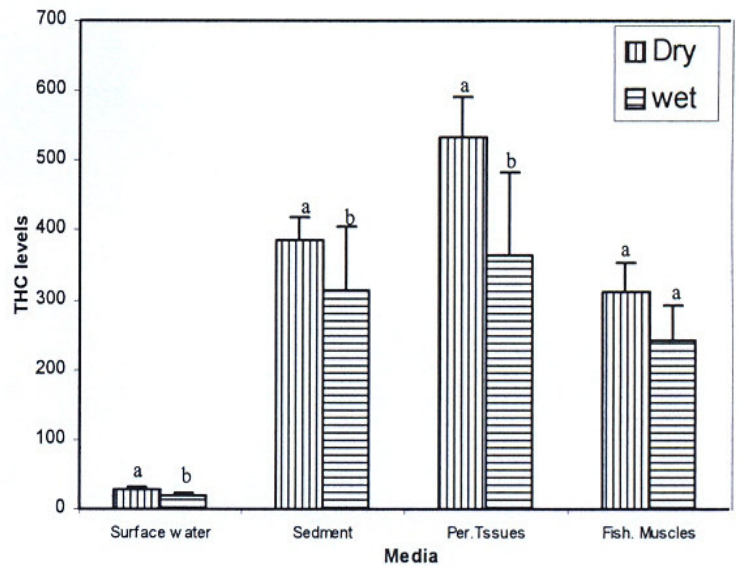

Figure 5. Seasonal variation of THC in the surface water $(m g / l)$, Sediment $(\mu g / g)$, Periwinkle tissues $(\mu \mathrm{g} / g)$ and Mudskipper fish muscles $(\mu g / g)$ from the study area. Note: Superscripts with different alphabets are significantly different $(P<0.05)$ 
Linear relationship analyses in the levels of THC between the biota (periwinkles and mudskippers) and their exposure media - surface water and sediment were all significant $\left(\mathrm{P}<0.01_{0.46}\right)$. The various bioaccumulation and correlation factors are as shown in Table 2. and Fig. 6.

Table 2. Bioaccumulaton factors and correlation coefficients of the periwinkles and mudskippers to surface water and sediment

\begin{tabular}{|c|c|c|c|}
\hline Organism & Exposure media & $\mathbf{K}_{\mathbf{b}}$ & $\mathbf{r}$ \\
\hline Periwinkle tissues & Surface water & 11.69 & 0.74 \\
\hline Periwinkle tissues & Sediment & 1.06 & 0.92 \\
\hline Mudskipper muscles & Surface water & 5.26 & 0.79 \\
\hline Mudskipper muscles & Sediment & 0.48 & 0.87 \\
\hline
\end{tabular}
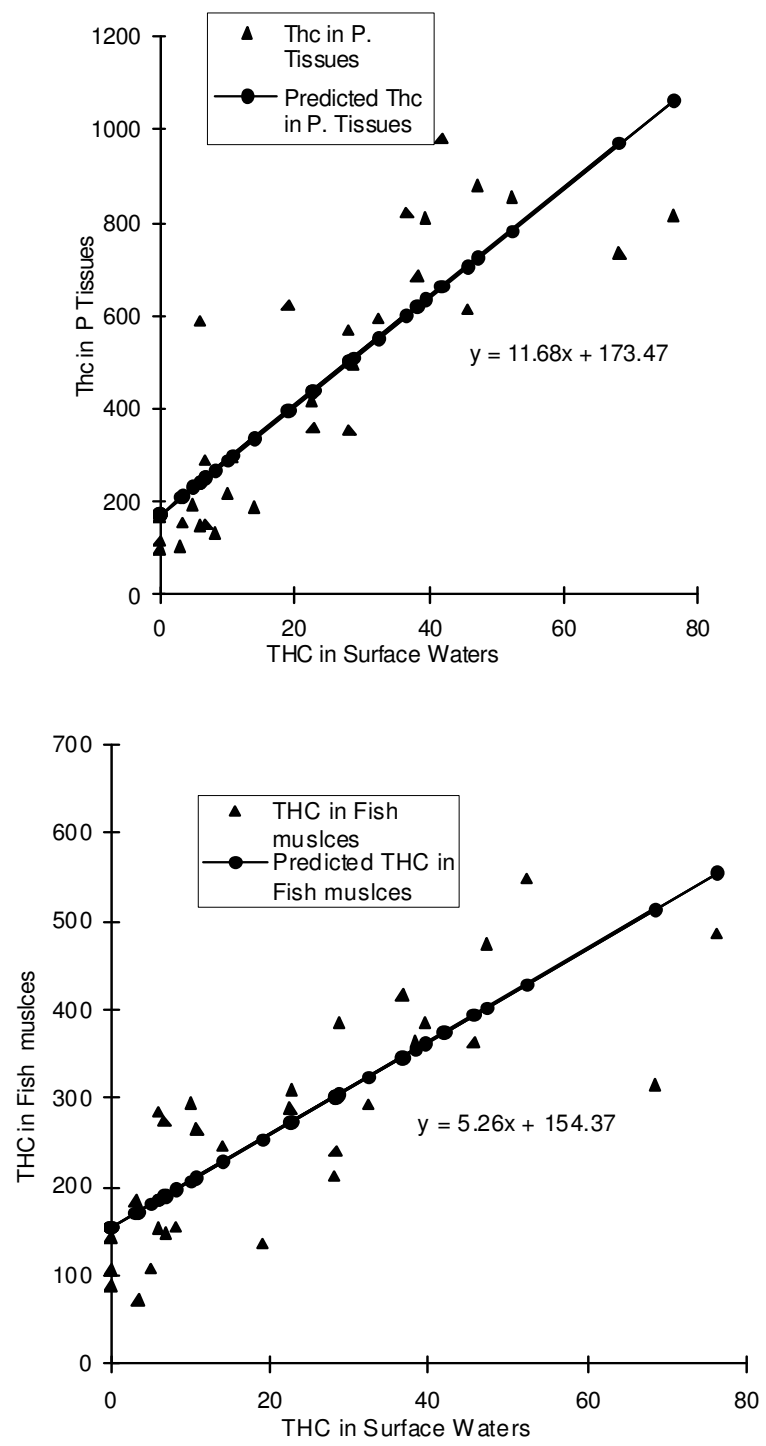

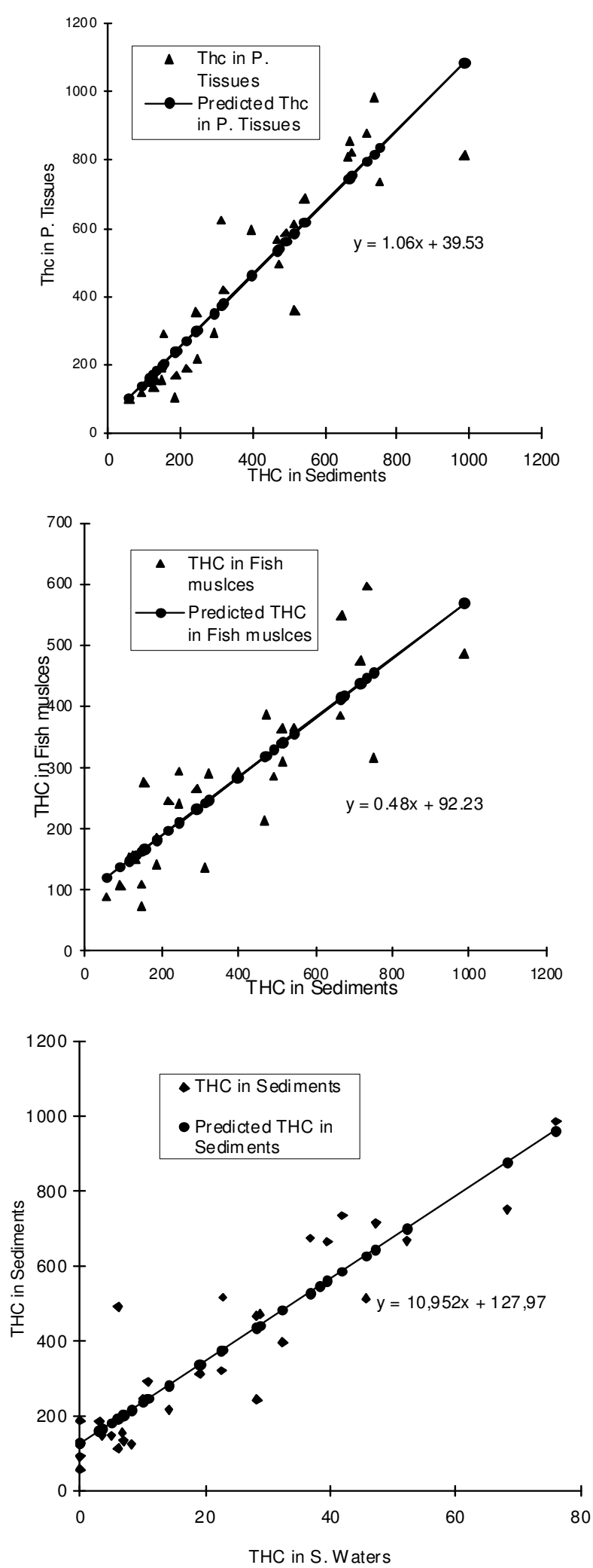

Figure 6. Relationship of the THC levels between the biota and the exposure media (Sediment and Surface water) of this study 


\section{Discussion}

Generally, higher total hydrocarbon concentrations were recorded in stations that have oil formations than those without oil formations. However, the high recorded in SSB, without formation, may imply input result from other sources like domestic wastes, discharge of sewage, drifts from polluted areas and other activities [15]. The level of THC contamination decreased significantly $(\mathrm{P}<0.05)$ between stations with wellheads and those without, possibly due to dilution effects which may have gradually lowered the level of total hydrocarbons from the inception of the sampling period (November 2001) when there was increase of oil activities within the study area to the end of the sampling period (October 2002). In addition, various chemical, physical and biological processes that are known to degrade petroleum hydrocarbon in water may undoubtedly have contributed to the general decrease in the hydrocarbon levels observed. THC levels in the dry season were higher than in the rainy season for the stations with wellheads contrary to the observations of some authors [16, 11 and 17]. However, in the non-oil formation stations (SSA and SSB), higher levels were recorded in the rainy season than in the dry season. The oil must have been washed into the river from land based sources during the rainy season in these stations, besides increased water current and wave action, which may largely disturb the sediment with the concomitant resurfacing of the previously leached hydrocarbon into the sediment [17]. It has been remarked that high temperatures and high rates of microbial activities are known to cause rapid degradation of petroleum hydrocarbons released into tropical environment [16].

The regression analysis indicates that the biota accumulated THC from their immediate environment. For instance from the regression equation, a unit increase of THC in the surface water of the study area will add 11.6 and 5.6 units of THC into the periwinkle tissues and mudskipper muscles respectively. This is also shown in the respective bioaccumulation factors. By implication both organisms (though the periwinkles were better off) were good accumulators and indicators of pollutants in effluents and other wastes in the river system. Again the sediment loads of THC all through the sampling periods and sites were consistently higher than that of the surface water indicating that it was a better indicator of pollution in the river system even after the sources of pollution has been removed.

High hydrocarbon content causes oxygen deterioration by reduction in gaseous diffusion through the surface film of oil with far reaching implications for the flora and fauna of the affected area [18]. The presence of oil on the mangrove floor as was observed in sample stations $\mathrm{C}$ and $\mathrm{E}$ for instance will encumber the decay process of the litters from mangroves, which ordinarily enhance the accumulation of organic matter. Also, oiling of the mangrove system may also lead to leaf loss or complete defoliation of the characteristic Rhizophora and Avicenma ssp mangrove seedlings in the affected areas [19] as was observed in station E. Shriveling, occupying-up of leaves, arrested expansion of buds and some degrees of foliar necrosis have also been identified as a mark of stress of a mangrove system plagued with petroleum hydrocarbons [12]. In a related field reconnaissance survey an abysmal decimation of juvenile red mangrove by oil spillage was observed along the Nembe axis of Niger Delta resulting from either short or long time exposure of the flora to toxic effects of the petroleum hydrocarbons [18]. It has also been noted that the growth of organisms that depend basically on primary producers (phytoplanktons and algae) and zooplanktons were always adversely affected under such conditions [6 and 20]. 
In the light of the forgoing the high mean surface water and sediment load of THC for stations $\mathrm{C}$ and $\mathrm{E}$ suggest that normal functioning of feeding, respiration and movement of benthic organisms may be adversely affected. Besides the levels in the $T$. fuscatus and P. papillio can have some health-risk implications in man who is the final consumer. The national permissible limit of total hydrocarbon/oil grease for inland water is $10 \mathrm{mg} / 1$ [21], while the WHO permissible level of THC in seafood is $0.001 \mu \mathrm{g} / \mathrm{g}$ [22]. This indicates that the study area was generally contaminated with petroleum hydrocarbon and the continuous consumption of seafood from the area may pose a public health hazard. However, the THC levels in the study area, was similar to that in other studies in the Niger Delta by [11]: surface water - $42.05 \mathrm{mg} / \mathrm{l}$ and sediment $184.89 \mu \mathrm{g} / \mathrm{g}$; [20] surface water - $149 \mathrm{mg} / \mathrm{l}$, sediment $-339.2 \mu \mathrm{g} / \mathrm{g}$ and biota $-196.9 \mu \mathrm{g} / \mathrm{g}$ and [23] sediment $-528.25 \mu \mathrm{g} / \mathrm{g}$.

The variation in the pattern of the total hydrocarbon within the study area suggests that most of the hydrocarbons in sediment, water and biota were of anthropogenic origin. The lower levels in the reference station A and at least station B suggest that these were the concentrations generally present in this area and anthropogenic source may have added to the aquatic media burden of total hydrocarbon in the environment. Moreover the FMENV's maximum discharge limit of 10mg/l THC/oil and grease into inland waters is less than the mean value in this study. This finding corroborates that of the World Bank [24] report that of all the 5,500 tons of hazardous wastes produced per year in Rivers State, the petroleum Industry, including the refineries generates most of them. There is therefore the need to develop management plan to ensure that petroleum hydrocarbon contamination of the area is prevented in order to achieve good aquatic life water quality and avoid any possible negative health out-break through consumption of contaminated marine resources by the local communities.

\section{REFERENCES}

[1] Thorhang, A. (1992): The involvement fortune of Kuwaits - In: Al-Shatti A.K. Hurigtion, J. M Eds. Proc. of International Symposium on the environment and the health impacts of the Kuwaiti oil fires, Edgbaston: The University of Birmingham Press

[2] Carbioch, L. Dauvin, J.C. and Gentil, F. (1977): Preliminary observations on pollution of the seabed and disturbance of sublitoral communities in Northern Brittany by oil from at the Amoco Cardiz. - Mar. Polut. Bull. 9: 303-307

[3] Farrington, J.W. Frew, N.M., Gschwed, P.W. and Tripp, B.W. (1977).: Hydrocarbons in North- Western Atlantic coastal and continental margin sediments. - Estuar. Coastal Mar.Sic. 5: 792-808

[4] Patin, S. (1999): Environmental Impact of the offshore oil and gas industry. - EcoMonitor East Northport, New York 425pp

[5] Howgate, P. (1977): Petroleum Tainting in Fish. Rapp P-V Reun Cons. - Inst. Explor. Mer. 171: 143-146

[6] Doerffer, J. W. (1992): Oil spill response in the marine environment. - Pergamon Press Headington Hill Hall, England.

[7] Dambo, W. B. (1992): Tolerance of the Periwinkles Pachymelania aurita (Muller) and Tympanotonus fuscatus (Linne) to Refined oils. - Environmental Pollution 79: 293-296

[8] Nwankwo, J. M and Irrechukwu, D.O. (1981): Problems of Environmental pollution control in the Nigerian Petroleum Industry. - The Petroleum Industry and the Nigerian environment Proceedings of the 1981 International Seminar p 1-20 
[9] Egonwan, I. R. (1980): On the Biology of Tympanotonus fuscatus var radula (Gastropoda: Prosobranchia, Potamidae) - M.Sc. Thesis. University of Lagos, Nigeria. $145 \mathrm{pp}$

[10] APHA American Public Health Association (1995): Standard Methods for the Examination of Water and Wastewater $15^{\text {th }}$ ed. - APHA-AWNA-WPCF. New York 1134

[11] Horsfall (Jr), M., Ogban, F.E. and Spiff, A. I. (1994): Petroleum hydrocarbon pollution:the distribution in sediment and water of the New Calabar River, Port Harcourt, Nigeria. - The Science of the Total Environment 141: 217-221

[12] Odu, C.T.I., Eurusoso O. F. and Nwobosh I.C. (1988): Environmental Study of the Nigerian Agip Oil Company Operational Areas, Soil, Fresh Water vegetation. University of Ibadan Press 46 pp

[13] ASTM (American Standard of Testing Materials) (1996): Test method for oil in water analysis. - Annual book of ASTM Standards Vol. ASTM International U.S.A.

[14] Wahua,T. A. T (1999): Applied Statistics for Scientific Studies. - Afrika-Link Books. Aba, Nigeria. P $129-249$

[15] Ahmed, S. M. (1983): Oil pollution studies in the Nile River. Survey of oil and grease in Nile water. - Environ. Int. 9:107-111

[16] Corredor, J. E.; Morell, J. M. and Del Castillo, C . E. (1990): Persistence of spills crude oil in the tropical intertidal environment. - Mar. Pollut. Bull., 21(8): 385-392.

[17] Chindah, A. C., Braide, A.S. and Sibeudu, O.C. (2004): Distribution of Hydrocarbons and heavy metals $\mathrm{n}$ sediment and a crustacean (shrimp - Penaeus notialis) from the Bonny New Calabar River Estuary, Niger Delta. - AJEAM-RAGEE 9: 1-17

[18] Osuji, L. C., Adesiyan S. O. and Obute, G. C. (2004): Post impact assessment of oil pollution in Agbada west plain of Niger Delta Nigeria: Field reconnaissance and total extractable hydrocarbon content. - Chem. Biodivers. 1: 1569-1577

[19] Ekewozor I.K.E. and Snowden, R. J. (1985): The studies of the impact of a minor oil spillage in the Upper Bonny estuary. - Paper presented at the NNPCFHME International Seminar on the Petroleum Industry and the Nigerian Environment, 1213 Nov. Kaduna, Nigeria.

[20] Eja, M. E., and Ogri, O. R. (2003): Evaluation of total hydrocarbon (THC) levels in oil polluted coastal areas of South Eastern Nigeria. - Global J. Environ. Sci. 2(1): 810.

[21] FMENV Federal Ministry of Environment (1992): Environmental Impact Assessment Decree 86, 1992 (Procedural Guidelines). - Published by the Federal Government Press, Lagos, Nigeria.

[22] Olaifa F. E. and Ayodele . A. (2004): Presence of hydrocarbons and heavy metals in some fish species $\mathrm{n}$ the Cross River, Nigeria. - African Journal of Livestock Extension 3: 90-95

[23] Ideriah, T.J.K., Braide A.S. and Briggs, O. A. (2006): Distribution of lead and total hydrocarbon in tissues of periwinkles (Tympanotonus fuscatus and Pachymelania aurita) in the Upper Bonny River, Nigeria. - J. Appl. Sci. Environ. Mgt 10(2): 145-150.

[24] World Bank (1995): Africa: A framework for Integrated Coastal Zone Management. Environmental Department World Bank Washington D. C. 